\title{
Section 2036 Proves Potent IRS Weapon Against Family Limited Partnerships
}

\author{
Debra M. Grace, (E-mail: dgrace@ csulb.edu), California State University at Long Beach
}

\begin{abstract}
Taxpayers' successful uses of Family Limited Partnerships (FLPS) to shield wealth from estate taxes and gift taxes are being challenged by the IRS with Code Section 2036. Sec. 2036 "pulls back" into the taxable estate all assets over which the taxpayer retains direct or indirect control, subjecting them to transfer taxes. These assets can include those transferred to FLPs where taxpayers act carelessly in conducting relationships with the entity. The IRS' use of Code Section 2036 has recently resulted in taxpayer losses in court and now represents the major challenge to a FLP's viability. To assist accountants and their clients engaged in FLPs, this article analyzes Sec. 2036 and details current tax developments, particularly the June 2003 decision in the remanded case of Strangi. The article also provides specific tax planning procedures for accountants to undertake when advising clients engaged in FLPs, so as to safeguard taxpayers' assets against Sec. 2036 attack.
\end{abstract}

\section{Introduction}

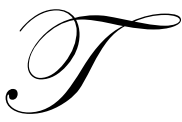

ransferring family wealth from one generation to another can be difficult and complex. The older generation may not wish to give up control of assets and any direct transfer of wealth to offspring may result in gift or estate taxes being levied. However, by using Family Limited Partnerships (FLPs), parents can minimize transfer taxes through valuation discounts and can also maintain control over the assets when serving as general partners of the FLP.

The use of FLPs to reduce gift and estate taxes has resulted in IRS challenges, with the government asserting the FLPs are sham devices formed only to escape transfer taxes. The courts have not been sympathetic to the IRS' line of attack. However, in recent years, the IRS has been winning cases against FLPs by using Code Section 2036, which subjects transferred assets to estate taxes if the decedent retained ownership rights in the assets or the ability to assign these rights to others.

This article examines how the IRS uses Sec. 2036 to ignore wealth transfers to FLPs, thus subjecting the assets to estate taxes. To assist accountants and their clients, the paper also provides specific tax planning advice for avoiding the reach of Sec. 2036. In many cases, Sec. 2036 can be avoided simply by minimizing taxpayers' carelessness in dealing with the FLPs. To provide the reader with an appropriate understanding of the use of FLPs to minimize estate taxes, the next section of this article illustrates the formation of a typical FLP.

\section{How the FLP Reduces Transfer Taxes}

Example One shows the first step in utilizing a FLP to transfer wealth to family members. FLPs must have at least one general partner and one limited partner, and typically, the limited partners will be family members, while the general partner is a corporation. Here, the taxpayer creates a FLP and a corporation by transferring assets worth $\$ 10$ million as follows: $\$ 100,000$ to the corporation for 100\% control and \$9.9 million to the FLP, receiving 99\% control. The corporation then transfers its cash to the FLP for a $1 \%$ general partnership interest. In this first step, there is no diminution of value in the assets. 
EXAMPLE ONE

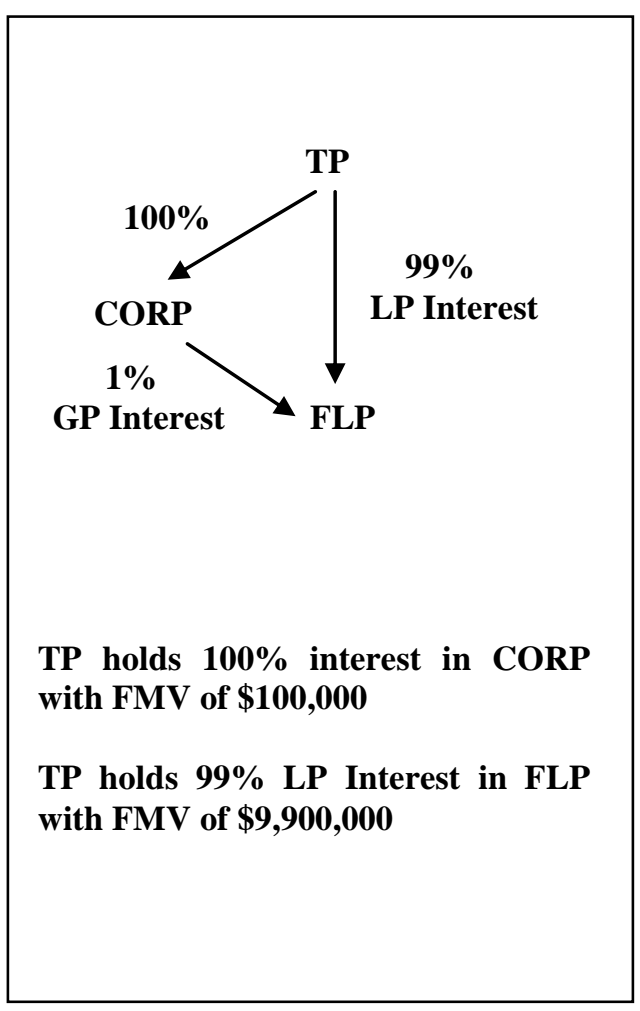

EXAMPLE TWO

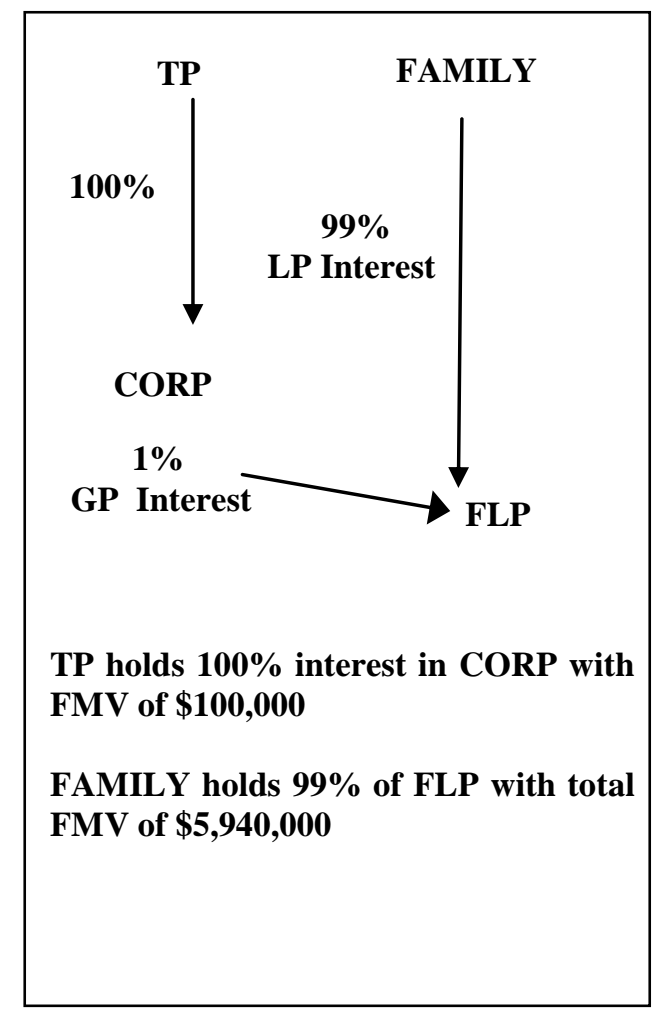

Example Two shows the final step in using the FLP to transfer the taxpayer's wealth to his family. Here, the taxpayer transfers all or substantially all of his limited partnership interest to family members. It is important to understand the taxpayers is not transferring actual assets at this point, but only a limited partnership interest in the FLP's assets.

Because the family members hold limited partnerships interests, they cannot directly control the assets or cause them to be distributed at will. Hence, the fair market value (FMV) of their ownership interests is reduced to reflect this limited control by the use of valuation discounts. These valuation discounts, in turn, reduce the dollar amount subject to transfer taxes. In this example, using a valuation discount of $40 \%$ has the effect of reducing the $\$ 9.9$ million FMV originally placed in the FLP to $\$ 5.94$ million, thus saving nearly $\$ 4$ million in wealth from transfer taxes.

It is this substantial removal of wealth from the transfer tax base that has raised the ire of the government. The IRS has responded with increasing audits of FLPs and has contested taxpayers' arguments assertively in court. The following section of this article details the IRS' arguments against FLPs.

\section{The IRS' Arguments Against FLPs}


By aggressively using valuation discounts to reduce transfer taxes, taxpayers now face IRS challenges in audit and in court. The IRS has attacked FLPs using the following arguments, which it details in two Field Service Advices to its agents: ${ }^{1}$

- Economic substance (business purpose)

- $\quad$ Sec. 2703

- $\quad$ Sec. 2704

- Gift on formation

- $\quad$ Sec. 2036

The first four arguments support attempts by the IRS to ignore the FLP's legal existence, which would make the full FMV of assets transferred subject to gift or estate taxes. However, the courts have overwhelmingly held against the IRS on these arguments. In particularly, the Tax Court has indicated that a FLP validly formed under applicable state law will not be ignored, despite lack of business purpose. ${ }^{2}$ In essence, the courts have said the legal restrictions imposed by a FLP so restrict the limited partners' control over the assets that the FMV of the partners' interests may be appropriately reduced by valuation discounts.

\section{Section 2036: An Area of Success for IRS}

However, Sec. 2036 remains the one area where the IRS has enjoyed and continues to enjoy success in court. In Strangi ${ }^{3}$, which was remanded back from the Fifth Circuit Court of Appeals for a rehearing on Sec. 2036, the taxpayer lost on this issue. Somewhat fortunately for the taxpayer in Strangi, no additional taxes were due, since the government had failed to assert an increased deficiency when raising the Sec. 2036 issue. ${ }^{4}$

In addition to Strangi, the IRS has employed Sec. 2036 to its advantage in a growing list of other recent cases. The following section explains the purpose of Sec. 2036 and highlights several of these cases, illustrating the flaws in taxpayers' interactions with their FLPs that led to court decisions against them.

\section{Using Section 2036 to Attack FLPs}

\section{How Section 2036 Operates}

Sec. 2036(a) operates to ignore certain asset transfers, subjecting them to estate taxes, if the taxpayer retains possession, enjoyment, or income rights to the property or has the ability to designate others who may hold such rights. ${ }^{5}$ For example, if a taxpayer transfers her home to a FLP but continues to live there rent-free until death, Sec. 2036 ignores the transfer and includes the home in the taxable estate. Thus, Sec. 2036 negates any valuation discounts, since the transfer of the property to the FLP is voided. Bona fide sales of property do not fall under Sec. $2036 .{ }^{6}$ Transfers of wealth as gifts during a taxpayer's lifetime do not fall under Sec. 2036, since the section deals only with estate taxes.

\section{Taxpayer Carelessness Ensures IRS Victories}

The IRS' victories in using Sec. 2036 have occurred only because taxpayers have dealt carelessly with FLPs. For example, in Reichardt, ${ }^{7}$ the taxpayer commingled FLP and personal funds ${ }^{8}$ and continued to live rentfree in a personal home transferred to the FLP. ${ }^{9}$ Similarly, in Schauerhamer, ${ }^{10}$ the taxpayer deposited partnership income into a personal checking account and paid personal expenses with the account. ${ }^{11}$ In the case of Strangi, ${ }^{12}$ recently heard for the second time in Tax Court following a remand from the Fifth Circuit to consider the issue of Sec. 2036, the taxpayer had the FLP pay personal medical expenses of his nurse and distribute assets at will to his children. ${ }^{13}$

Likewise, in the recent cases of Thompson ${ }^{14}$ and Harper, ${ }^{15}$ the IRS successfully used Sec. 2036 to ignore valuation discounts claimed by the taxpayers on transfers to FLPs. In Thompson, the FLP made disproportionate cash distributions to the taxpayer to permit him to continue making holiday gifts to family members and also paid 
personal expenses of family members from FLP funds. ${ }^{16}$ In Harper, there was commingling of FLP and personal funds and disproportionate cash distributions to the taxpayer. ${ }^{17}$

\section{Byrum Defense Falls in Strangi II}

Historically, tax practitioners felt the 1972 Supreme Court case of Byrum $^{18}$ acted to protect a general partner from Sec. 2036(a)(2)'s prohibition against designating others who could enjoy the rights of transferred assets. Even though the taxpayer might control the general partner through stock ownership, the fiduciary constraints that applied under state law to the taxpayer/general partner would operate to protect the assets from uncontrolled distributions.

However, in the second rehearing of Strangi, the IRS argued and the Tax Court agreed, that the Byrum doctrine failed to shield the assets Strangi placed into the FLP from the reach of Sec. 2036. ${ }^{19}$ Strangi was able to both retrieve assets for personal use and was able to designate others who could receive them at will, thus negating the general partner's fiduciary duties to other limited partners. The court essentially dismissed any argument that the general partner in Strangi acted on behalf of all limited partners, as it noted that Strangi's children received no meaningful economic stake in the property during his life, while instead large sums were advanced for Strangi's expenditures. ${ }^{20}$ The children held an implied understanding that Strangi's access to the assets would not be restricted. $^{21}$

The next section of this article lists the elements of taxpayer carelessness in dealing with their FLPs which prompt Section 2036 attack by the IRS. By paying careful attention to the areas listed below, taxpayers using FLPs to transfer assets at death can avoid application of Sec. 2036 and thus minimize estate taxes.

\section{Elements of Taxpayer Carelessness Inviting Section 2036 Attack} attack:

Here are the elements of carelessness that contribute to the taxpayers' FLPs being subjected to Sec. 2036

- Commingling of FLP and personal funds

- Not dealing at arm's-length with the FLP

- Making disproportionate, or non-pro-rata distributions to taxpayer

- Leaving taxpayer with insufficient personal assets after FLP transfer

- General partner does not manage FLP

The following sections discuss these elements and offer examples from recent cases involving Sec. 2036. In all instances, it is important to observe that the carelessness of the taxpayer arises because he or she fails to respect the existence of the FLP. The taxpayer behaves as if he or she is still the sole owner of the assets, instead of recognizing that the FLP is now the owner.

\section{Commingling of FLP and personal funds}

When taxpayers commingled FLP funds with their personal cash, they act to ignore the FLP's existence. While co-mmingling of funds is not sole determinant that the IRS will use in applying Sec. 2036 to ignore the transfer of assets to the FLP, it is an element which, when added to the other elements, makes the cumulative case against the taxpayer and for the IRS.

In the Estate of Reichardt v. Commissioner, ${ }^{22}$ the taxpayer mixed partnership and personal funds by depositing partnership income into a personal account and then using the partnership's checking account to pay his personal expenses. ${ }^{23}$ Similarly, in Dorothy Schauerhamer, ${ }^{24}$ the taxpayer managed her assets and income exactly as she did before the transfer to the FLP. She deposited FLP income into a personal account and then paid both business and personal expenses from the same account. ${ }^{25}$ 
In Harper ${ }^{26}$ the taxpayer and his children failed to set up separate bank accounts for the FLP after its formation, which led the decedent to commingle personal funds with the partnership funds. ${ }^{27}$ Likewise, in Thompson, ${ }^{28}$ the taxpayer placed both FLP funds and personal funds into the same bank account and proceeded to pay personal expenses from the account.

When partnership and personal funds are commingled in one account, the Tax Court will likely find that Sec. 2036 applies, since the taxpayer's relationship to his wealth remains unchanged despite its purported transfer to the FLP. Failure to quickly set up separate business bank accounts for the FLP or to obtain Federal identification numbers, or appropriate business licenses and permits will make it much easier for the government to assert that the transferor retains control over the assets transferred to the FLP. Similarly, when the taxpayer fails to deal at arm'slength with the entity as the next section discuses, the courts will regard this as further reinforcement for application of Sec. 2036.

\section{Not dealing at arm's-length with the FLP}

When assets are transferred to the FLP, taxpayers must respect the changed ownership over those assets. This element has been increasingly violated by taxpayers who transfer their personal residences to their FLPs, yet continue to reside there without paying rent to the owner of the house-the FLP. While the taxpayer's lawyer in Strangi II noted that rent had been accrued by the FLP for the time Strangi resided there, the court was quick to point out that the FLP did not receive any cash payments for two years from the taxpayer ${ }^{29}$--a situation that would not be tolerated by a tenant and landlord engaged in an arm's length economic arrangement. Likewise, in Reichardt ${ }^{30}$, the decedent transferred his home to the FLP but continued to live there rent-free.

In Thompson ${ }^{31}$ the FLP lent money to the taxpayer's family members, but collected interest payments late or not at all. The FLP took no legal action against family members who failed to make principal or interest payments on the loans.

To avoid Sec. 2036, taxpayers must pay rent or interest equal to fair market value when using FLP assets, or borrowing FLP funds. All such arrangements should be documented and recorded in FLP records. Failure to do so strengthens the government's case that the FLP's existence can be ignored. Further, the legal title to the assets transferred to the FLP should follow the assets. There should be no delay in transferring the titles.

Another element of risk exists when the taxpayer, acting as general partner, causes the FLP to make nonpro-rata, or disproportionate distributions to him or her, in violation of FLP partnership agreement provisions that generally provided for pro-rata distributions to limited partners. This area is discussed in the following section.

\section{Making disproportionate, or non-pro-rata distributions to taxpayer}

When the taxpayer, as a limited partner in the FLP, receives more than his pro-rata share of distributions, this strengthens the IRS case that the taxpayer has retained control over the FLP assets and hence, Sec. 2036 should apply. All distributions to limited partners should follow the guidelines set down in the FLP partnership agreement, which will generally require pro-rata, or proportionate distribution of assets at the direction of the general partner. Distributions to partners should be make at the same time and should be proportionate in amount, based on the limited partners' ownership interests in the FLP. Further, the business reasons for all FLP distributions should be carefully documented in FLP minutes.

In the second hearing in Strangi, ${ }^{32}$ the Tax Court noted the number of disproportionate, or non-pro-rata distributions to the taxpayer from the FLP that violated the partnership agreement. The court noted that very little changed in the taxpayer's relationship to his wealth, beyond formal title transfers of the assets to the FLP. ${ }^{33}$ In Thompson, disproportionate distributions were made to the taxpayer so he could continue his gift-giving tradition to family members. ${ }^{34}$ Likewise, in Harper, there was a history of disproportionate distributions to the taxpayer. ${ }^{35}$ 
In many of these cases, the impetus for the disproportionate distributions to the taxpayer comes from the fact that the taxpayer is asset-poor, having transferred all or substantially all of his assets to the FLP. Thus, the taxpayer looks continually to the FLP for distributions of assets to meet his normal living expenses. The next section discusses the drawbacks to contributing the bulk of the taxpayer's assets to the FLP

\section{Leaving taxpayer with insufficient personal assets after FLP transfer}

In Strangi, the Tax Court noted the taxpayer had contributed substantially all of his wealth to the FLP, leaving him with inadequate ability to finance his living costs. ${ }^{36}$ In fact, the taxpayer had little left beyond two bank accounts with funds totaling $\$ 762 .^{37}$ It is no wonder the taxpayer had to make continual appeals for distributions from the FLP. The taxpayer in Harper also transferred the bulk of his assets to the FLP, requiring the FLP to make non-pro-rata distributions to him to meet his normal living expenses. ${ }^{38}$ This was also the case in Reichardt ${ }^{39}$ where the decedent retained only a small portion of his assets (a car, personal effects and a small amount of cash) after contributing the bulk of his wealth to the FLP.

When all or substantially all of the taxpayer's assets are transferred to the FLP, the IRS will argue that an implied agreement exists among the remaining family limited partners for the transferor to continue using the assets as he did before the transfer. This was the court's finding in Strangi. ${ }^{40}$ Likewise, in Harper, ${ }^{41}$ the Tax Court concluded the only rational explanation for the taxpayer's contribution of substantially all his wealth, even that needed to cover living expenses, was that the other limited partners, his children, would agree to his requests for money from the FLP. This implied agreement also triggered Sec. 2036.

A better procedure is to have the taxpayer retain enough personal assets and funds with which to meet his normal living expenses and transfer only wealth in excess of these amounts to the FLP. If this is done, then the problem of disproportionate distributions from the FLP to the taxpayer simply to meet personal expenses will disappear and the IRS will have one less element with which to attack the FLP using Sec. 2036.

\section{General partner does not manage FLP}

The general partner has a fiduciary duty under state law to manage the partnership and to ensure that distributions to limited partners are made on a pro-rate basis. If the general partner's actions benefit one, but not all limited partners, the IRS may argue the benefited partner has control over the assets and the FLP should be ignored. The limited partners should conduct no management functions, since this violates the partnership agreement.

The general partner should receive reasonable compensation for managing the FLP and should ensure that a timely transfer of legal titles to assets takes place following the contribution of the assets to the FLP from the taxpayer. Further, the general partner should hold regular meetings of the FLP and record minutes reflecting the services the general partner provides the FLP. The general partner should secure taxpayer identification numbers for the FLP, ensure that tax returns are prepared and filed on a timely fashion.

\section{Conclusions}

The use of Family Limited Partnerships to transfer wealth from parents to children has withstood many challenges by the IRS in recent years. The most recent attacks by the IRS on FLPs using Section 2036 can be withstood by the careful accountant and his tax client, provided certain tax planning steps are taken, as discussed in this article. It is only the taxpayer's carelessness in dealing with the FLP that invites the IRS' use of Sec. 2036.

In particular, the accountant must ensure that his client respects the validity of the FLP and deals with it at all times in an arm's-length arrangement. The FLP cannot be viewed as a continuation of the client's personal pocketbook - distributions to limited partners must be made in pro-rata fashion if the FLP is to be respected by the IRS. In particular, where the taxpayer continues to use assets transferred to the FLP, such as a personal home, the taxpayer must make rent payments at fair market value to the FLP. Further, the taxpayer should not transfer all his wealth to the FLP to avoid finding himself in the situation of having to request disproportionate distributions from 
the FLP merely to meet normal living expenses. By acting to respect the FLP as a separate entity, the taxpayer can ensure transfer of family wealth to family members, reduce the burden of estate taxes and avoid the challenge of Section 2036.

\section{Endnotes}

${ }^{1}$ IRS National Office Field Service Advice (FSA) 200049003, 12/8/2000 and IRS National Office Field Service Advice (FSA) 200143004, 7/5/2001.

${ }^{2}$ See Estate of Albert Strangi, 115 TC 478. (2000), aff'd in part and rem'd in part by Gulig v. Commissioner, 89 AFTR 2d 2002-2977 (CA-5, 2002). Reheard by Tax Court in Estate of Albert Strangi, TC Memo 2003-145, 5/20/2003. Also, see Ina F. Knight, 115 TC 506 (2000).

${ }^{3}$ Estate of Albert Strangi, TC Memo 2003-145, 5/20/2003.

${ }_{5}^{4}$ Estate of Albert Strangi, TC Memo 2003-145 at 747. 5/20/2003.

${ }_{6}^{5}$ Sec.2036(a)(1) and (a)(2).

${ }^{6}$ Sec. 2036(a).

${ }^{7}$ Estate of Charles E. Reichardt, 114 TC 144 (2000).

${ }^{8}$ Estate of Charles E. Reichardt, 114 TC 144 at 152 (2000).

${ }^{9}$ Estate of Charles E. Reichardt, 114 TC 144 at 149 (2000).

${ }^{10}$ Dorothy Schauerhamer, TC Memo 1997-242, RIA TC Memo II97242, 73 CCH TCM 2855.

${ }^{11}$ Dorothy Schauerhamer, TC Memo 1997-242 p. 1504. RIA TC Memo 『[97242, 73 CCH TCM 2855.

${ }^{12}$ Estate of Albert Strangi, 115 TC 478. (2000), aff'd in part and rem'd in part by Gulig v. Commissioner, 89 AFTR 2d 2002-2977 (CA-5, 2002). Reheard by Tax Court in Estate of Albert Strangi, TC Memo 2003-145, 5/20/2003.

${ }^{13}$ Estate of Albert Strangi, 115 TC 478 at 495. (2000), aff'd in part and rem'd in part by Gulig v. Commissioner, 89 AFTR 2d 2002-2977 (CA-5, 2002). Reheard by Tax Court in Estate of Albert Strangi, TC Memo 2003-145, $5 / 20 / 2003$.

${ }^{14}$ Estate of Theodore R. Thompson, TC Memo 2002-246.

${ }^{15}$ Estate of Morton B. Harper, TC Memo 2002-121, RIA TC Memo II2002-121, 83 CCH TCM 1641.

${ }^{16}$ Estate of Theodore R. Thompson, TC Memo 2002-246.

${ }^{17}$ Estate of Morton B. Harper, TC Memo 2002-121, RIA TC Memo I2002-121, 83 CCH TCM 1641.

${ }^{18}$ United States v. Byrum, 408 U.S. 143 (1972), 30 AFTR 2d 72-5811, 33 L Ed 2d 238, 72-2 USTC \112859.

${ }^{19}$ Estate of Albert Strangi, TC Memo 2003-145 at 742. 5/20/2003.

${ }^{20} \mathrm{Ibid}$. at 740.

${ }^{21}$ Ibid.

${ }^{22}$ Estate of Charles E. Reichardt, 114 TC 144 (2000).

${ }^{23}$ Estate of Charles E. Reichardt, 114 TC 144 at 152 (2000).

${ }^{24}$ Dorothy Schauerhamer, TC Memo 1997-242, RIA TC Memo 997242,73 CCH TCM 2855.

${ }^{25}$ Dorothy Schauerhamer, TC Memo 1997-242 p.1504. RIA TC Memo đ[97242, 73 CCH TCM 2855.

${ }^{26}$ Estate of Morton B. Harper, TC Memo 2002-121, RIA TC Memo \[2002-121.

${ }^{27}$ Ibid.

${ }^{28}$ Estate of Theodore R. Thompson, TC Memo 2002-246, RIA TC Memo \[2002-246.

${ }^{29}$ Ibid.

${ }^{30}$ Estate of Charles E. Reichardt, 114 TC 144 (2000).

${ }^{31}$ Estate of Theodore R. Thompson, TC Memo 2002-246, RIA TC Memo I[2002-246.

${ }^{32}$ Estate of Albert Strangi, TC Memo 2003-145, 5/20/2003.

${ }^{33}$ Ibid. at 740.

${ }^{34}$ Estate of Theodore R. Thompson, TC Memo 2002-246, RIA TC Memo I[2002-246.

${ }^{35}$ Estate of Morton B. Harper, TC Memo 2002-121, RIA TC Memo I[2002-121.

${ }^{36}$ Estate of Albert Strangi, TC Memo 2003-145 at 739, 5/20/2003.

${ }^{37}$ Ibid.

${ }^{38}$ Estate of Morton B. Harper, TC Memo 2002-121, RIA TC Memo I[2002-121.

${ }^{39}$ Estate of Charles E. Reichardt, 114 TC 144 (2000).

${ }^{40}$ Estate of Albert Strangi, TC Memo 2003-145 at 740, 5/20/2003.

${ }^{41}$ Estate of Morton B. Harper, TC Memo 2002-121, RIA TC Memo I[2002-121. 
Notes 